\title{
Per a qui traduïm Ibsen avui?
}

\author{
Carolina Moreno Tena \\ Universitat de Barcelona. Departament de Filologia Anglesa i Alemanya \\ Gran Via de les Corts Catalanes, 585 \\ 08007 Barcelona \\ carolina.moreno@ub.edu
}

\begin{abstract}
Resum
En aquest article ens preguntem per a qui traduïm les obres de Henrik Ibsen avui per tal de reflexionar no només sobre la necessitat de retraduir els clàssics, sinó per a què, si és per consolidar unes nocions de clàssic i de cànon ja superades o per donar-li de nou la veu als escenaris perquè pugui tornar a commoure els espectadors i a inspirar directors i autors teatrals contemporanis. I sobretot com podem enfocar aquestes retraduccions per revestir-lo d'una universalitat renovada basada en la seva força i originalitat literària.
\end{abstract}

Paraules clau: Ibsen; teatre; retraducció; cànon; literatura universal

Abstract. For whom do we translate Ibsen today?

In this article I aim to answer the question Who is the reader of the translations of Ibsen's playwrights? To find out the answer will help me not only to think about the necessity of retranslating the classics but also about who is the receptor of these retranslations. Depending on the answer we'll consolidate the concepts of classic and canon that has already been overcome, or we'll give a new life to the characters and plots on the stage for moving the spectator and inspiring contemporary directors and authors. And the most important thing, as I understand it, is to know how do we face these retranslations in order to give a new universality based on the creative craft and originality of Ibsen's literary works.

Keywords: Ibsen; theatre; retranslation; canon; world literature

He encapçalat aquest article amb la pregunta «Per a qui traduïm Ibsen avui?» perquè penso que és clau a l'hora de reflexionar sobre el fenomen de la retraducció, aquest espai entre l'inconformisme $\mathrm{i}$ el cànon sobre el qual versen les Jornades sobre Traducció i Literatura Jordi Arbonès d'enguany, i ho és en dos sentits: la resposta pot fer-nos de guia en l'especulació sobre les virtuts i els conflictes de la retraducció, i el cas d'Ibsen dona molt de joc atesa la seva actualització constant dalt dels escenaris de tot el món. 
La universalitat d'Ibsen és innegable i un cas evident de la teoria de Pascale Casanova quan defineix la traducció com una de les vies principals de consagració d'una obra o d'un autor en l'espai literari mundial. El noruec entraria en una de les quatre categories de llengües dominades, la dels «països petits», les que tenen una història relativament important, pocs parlants, són poc practicades pels poliglots i poc conegudes fora de les fronteres nacionals; ras i curt, són poc valorades en el mercat literari internacional (Casanova 2002). Ibsen es va donar a conèixer en els escenaris de París i d'Alemanya; per tant, va ser conegut mitjançant les traduccions alemanyes i franceses, que van arribar a Barcelona al final del segle XIX i al començament del Xx, respectivament. ${ }^{1}$

Dit això, cal distingir aquests dos contextos de recepció, atès que, malgrat que tots dos són igual d'interessats (en termes de Pierre Bourdieu), les intencions, les circumstàncies i les conseqüències són ben diferents: d'una banda, els traductors de la Barcelona del final del segle XIX tenien la necessitat de crear un contrapol dins el camp literari propi i alterar-lo. Les obres d'Ibsen no es van importar únicament pel valor literari sinó, per la seva força revulsiva tant des d'un punt de vista formal — la renovació del drama burgès—, temàtic — calia fer trontollar «els pilars de la societat»— i lingüístic gràcies a l'impuls de regeneració lingüística que el dramaturg del nord va dur a terme per mitjà d'un procés de desdanificació fonètic, ortogràfic, sintàctic i lexicogràfic de la llengua noruega. Era qüestió de norueguitzar la llengua escrita, la llengua de cultura, que s'havia anat sotmetent a la danesa a causa de la prolongada annexió de Noruega a la corona danesa, i fer-ho a partir del noruec parlat arreu del país, del noruec colloquial que s'havia conservat oralment. Al mateix temps, al seu entendre calia modernitzar la llengua literària acostant-la al registre del noruec quotidià que es parlava en aquell moment $i$ aconseguir així un efecte realista i una immediatesa que connectés l'obra de teatre amb l'espectador d'una manera més directa i, per tant, més eficaç.

D'altra banda, al segle xx, les traduccions de l'alemany de Feliu Formosa es van fer amb el propòsit de traduir obres universals per tal que, en termes de Casanova encara, la literatura catalana acumulés capital literari amb la traducció d'obres universals o, explicat des de la teoria dels polisistemes d'Itamar EvenZohar, seria un cas de literatura perifèrica a la qual manca repertori o no pot desenvolupar totes les activitats literàries i necessita els models de literatures més completes per construir una identitat literària pròpia. En aquest cas, Ibsen serviria d'inspiració als escriptors o dramaturgs en llengua catalana que volguessin nodrir-se d'altres propostes per enriquir i construir la pròpia, tant individualment com collectivament. De fet, aquesta és una de les idees que van ajudar Goethe a forjar la seva noció de Weltliteratur, empès, entre d'altres raons, per la voluntat

1. Sobre la recepció d'Ibsen a Catalunya al tombant del segle XIX al XX, vegeu Carles Batlle a Adrià Gual (1891-1902): per un teatre simbolista i Siguan, M.: La recepción de Ibsen y Hauptmann en el Modernismo catalán, PPU, 1990; sobre la traducció d'Ibsen a Catalunya, vegeu Moreno, C.: «'A èpoques noves, formes d'art noves': Ibsen a Catalunya», a García, Roig, Zaboclicka (ed.), Traducció Indirecta en la Literatura Catalana, Barcelona, Punctum, 2014 (p. 93-116). 
de dotar la literatura alemanya d'una identitat i situar-la al centre de la literatura europea. La traducció era cabdal en aquest procés, tant per a ell com per als romàntics alemanys. Era l'eina que feia possible la construcció de la identitat passant per l'alteritat, nodrint-se de l'altre.

La traducció, doncs, és determinant en la consagració i universalització d'Ibsen, perquè situa la seva obra i la literatura noruega en l'espai literari mundial, en el cànon de la literatura universal. Tant és així que el Center for Ibsen Studies de la Universitat d'Oslo va engegar un projecte de revisió de les traduccions de les seves obres a les llengües més importants, després de constatar que les traduccions existents al xinès, al rus i a l'espanyol necessitaven aquesta revisió perquè fins al moment s'havia imposat la traducció indirecta.

El projecte porta per nom Ibsen in Translation, va començar el 2009 i encara no ha acabat. Consisteix a traduir directament del noruec dotze drames contemporanis, des de Solness el constructor fins a Quan despertem d'entre els morts, a vuit llengües: l'àrab clàssic, l'àrab egipci, l'indi, el rus, el castellà, el japonès, el xinès i el persa, llengües que Casanova inscriu en el quart grup, les de gran difusió i les quals, tot i que disposen de grans tradicions literàries i un gran nombre de parlants, són poc reconegudes en el mercat literari internacional. Tanmateix, precisament projectes com Ibsen in Translation evidencien que aquesta categorització avui dia ja es van superant. En el seu moment, però, aquestes llengües havien incorporat l'obra d'Ibsen per traducció indirecta per mitjà de les llengües dominants en l'espai literari mundial, l'anglès o l'alemany.

Vist així, no es pot obviar la intenció del Center for Ibsen Studies per situar Ibsen i la literatura noruega al món en el seu sentit més extens i, de retruc, salvar la limitació restrictiva de la idea d'universalitat derivada de la confusió de literatura universal i literatura occidental.

Per a Ellinor Kolstad, traductora del rus i participant en el projecte, és evident que la traducció d'una obra en condiciona la recepció (se'n va adonar arran de la descoberta xocant d'un Txèkhov diferent gràcies a les posades en escena d'una nova traducció directa del rus en què no s'havia suprimit el seu «singular sentit de l'humor» i, per tant, no era un Txèkhov tan trist ni melancòlic que els noruecs tenien en ment). La conclusió que en va treure Kolstad va ser que calia esbrinar quin Ibsen arribava als escenaris del món, atès que gairebé sempre es feia per via indirecta, $i$, un cop comprovat que no deia el mateix ni de la mateixa manera que en noruec, calia tornar a l'original i fer noves traduccions que fossin fidels, no al text, sinó al llenguatge teatral d'Ibsen i recuperar tot el que s'havia perdut: els matisos, la proximitat a la parla quotidiana, a l'oralitat, l'ús d'un llenguatge contemporani amb termes actuals, renecs fins i tot, de la ironia, de la construcció subtil d'un parlar diferent que defineix alguns personatges, i sobretot, la seva riquesa i imaginació en l'ús de jocs de paraules, repeticions, errors de pronunciació o termes poc freqüents per sorprendre el lector i produir un efecte determinat.

Calia recuperar l'Ibsen modernitzador i realista, el del llenguatge contemporani, però també l'alta volada literària d'una escriptura entesa com un joc lingüístic que explora i inventa, que basteix personatges $\mathrm{i}$ accions alhora que enriqueix la llengua literària. 
Posarem un exemple: l'adjectiu vidunderlig, que apareix a Casa de nines de manera intencionalment reiterada. El terme surt en tots tres actes, però és revelador en l'últim perquè apareix en la darrera rèplica en la forma superlativa. Vidunderlig prové de vidunder, 'meravella', 'prodigi', 'miracle' i fa referència a allò que és «meravellós». En el primer acte, Nora l'utilitza per descriure el seu estat d'ànim i és sinònim de felicitat («És meravellós!»); en el segon acte, quan ja veu les orelles al llop («ara el que ha de passar és un miracle»), i, en el tercer acte, espera que es produeixi «el més gran dels miracles») quan es troba sense sortida, sigui el suïcidi, la fugida o que Torvald la comprengui. La reiteració en l'ús del mateix terme amb significats diferents, però en una escala de menys a més intensitat que va de començament a final és un recurs narratiu que intensifica l'acció.

Però el que més ens interessa des del punt de vista literari és que es tracta d'un terme molt noruec, que només els noruecs entenen en totes les connotacions i matisos, tal com reconeixia Herman Bang, l'escriptor danès que va dirigir Casa de nines a París el 1894. Ell mateix dona la mesura de fins a quin punt n'era de particular i especial, el terme vidunderlig, quan, en un article sobre l'experiència de dirigir la posada en escena de Maison de poupée, explica que el mot havia provocat una certa hilaritat entre els lectors per resultar una mica massa «affekteret», amanerat, i confessa que aquest mot només l'entenien els noruecs, la qual cosa denotava una manera d'expressar-se i de ser diferent respecte als altres pobles escandinaus. És clar que aquesta especificitat en dificulta la interpretació i, sobretot, l'intent de traslladar-lo correctament a l'escenari si alhora es vol conservar la virtuositat del terme i la seva rellevància en el desenvolupament de la trama $\mathrm{i}$ l'acció teatral. Tanmateix, la tria d'aquest terme li dona un plus, reforça la capacitat comunicativa del text i esdevé una de les paraules clau en l'anàlisi literària i dramàtic de l'obra.

A l'hora de traduir-lo es planteja el dilema entre conservar la reiteració o optar per aquelles solucions que donin més eficàcia comunicativa al text. Deixant al marge ara el condicionant de l'oralitat, l'aquí i l'ara del llenguatge teatral, que abordarem més endavant, la resposta al dilema a l'hora de traduir aquesta singularitat té relació directa amb l'espectador i, per tant, amb la pregunta que encapçala l'article, per a qui traduïm Ibsen avui.

La Institució de les Lletres Catalanes, per iniciativa d'Oriol Ponsatí-Murlà, em va convocar a una reunió juntament amb d'altres traductores del noruec per sondejar la possibilitat de fer el mateix en llengua catalana. La proposta era engrescadora pel repte en si i perquè situava el traductor al centre del projecte, cosa que reconeixia la rellevància de la tasca del traductor en qualsevol sistema literari. Fins i tot havia de servir d'estímul perquè els traductors d'altres literatures petites o perifèriques s'animessin a fer el mateix amb un altre autor que consideressin important.

El repte obria tot un reguitzell d'interrogants, com ara quines obres calia traduir i quines retraduir, atès que el llistat de traduccions existents no és curta gràcies a l'interès que Ibsen ha suscitat des del final del segle XIX. Evidentment, aquí entraríem en el debat sobre la necessitat de retraduir les que han envellit i cal 
actualitzar. Al meu entendre aquest és un dels criteris més clars, però quan el factor determinant és el fet que sigui indirecta, sorgeixen els dubtes. És el cas de les traduccions de Feliu Formosa. Tant Casa de nines com Hedda Gabler van ser revisades per mi acarant-les amb l'original amb l'objectiu de corregir possibles errors i ajustar qüestions de registre. Ara bé, la traducció d'una obra de teatre exigeix tenir en compte l'oralitat, una condició determinant en el teatre a diferència de la prosa, que té una relació diferent amb l'original pel que fa a la fidelitat al text. Cal tenir un gran coneixement del llenguatge teatral, de les característiques del gènere i de la llengua d'arribada perquè l'obra flueixi dalt de l'escenari; demana flexibilitat i trobar solucions imaginatives per fer-li dir el mateix que l'original i amb la mateixa eficàcia comunicativa. És per aquesta raó que les traduccions indirectes de Feliu Formosa funcionen perfectament malgrat no ser del noruec. Per tant, fins a quin punt la seva condició d'indirecta ha de ser sinònim d'obligada retraducció?

La reflexió sobre si han de prevaldre les exigències del gènere, que el text flueixi dalt de l'escenari o la literalitat de l'original és necessària, i així ho fa notar Cristina Gómez Baggethun, traductora al castellà del projecte, quan explica els desafiaments que es va trobar en afrontar la traducció d'Ibsen i admet que va partir de la convicció que calia ser fidel, però va haver de cedir a l'oralitat i a la immediatesa del teatre (Gómez 2016).

En el cas d'Ibsen, la seva posició respecte de la traducció ens ajuda a resoldre el dilema quan ens hi trobem com a traductors, i és que en una carta a Frederik Gjertsen el 21 de març de 1872, diu:

Traduir bé és difícil. No només es tracta de traduir el significat, sinó també de reescriure en certa manera l'expressió i les metàfores, així com adaptar la forma exterior a l'estructura i les necessitats de la llengua a la qual es tradueix. (...) Vull dir que un poema s'ha de traduir tal com l'escriptor l'hauria escrit si pertanyés al poble per al qual és traduiit. ${ }^{2}$

No cal dir que aquesta posició afavoreix l'efectivitat en detriment de la literalitat, i dona més pes a la força comunicativa del text.

La iniciativa de la ILC obria d'altres interrogants, per exemple: què en fèiem, de les traduccions directes existents? És el cas de Solness el constructor, de l'Anne-Lise Cloetta, o Un enemic del poble, de Jem Cabanes. Calia fer-les totes de cap i de nou i amb una revisió de conjunt per mantenir una certa uniformitat? En aquest cas, on arriben els límits d'aquesta uniformitat? Calia consensuar uns criteris de traducció perquè érem quatre traductores diferents? Els traductors del projecte Ibsen in Translation havien assistit a seminaris amb especialistes de

2. «At oversætte godt er en vanskelig sag. Det gælder jo ikke blot at oversætte meningen, men også til en viss grad at omdigte udtrykket og billederne samt endelig at lempe den ydre form efter det sprogs struktur og behov, hvori man oversætter. (...) Jeg mener, et digt bør oversættes således, som forfatteren selv vilde have digtet det, hvis han havde tilhørt det folk, for hvilket han oversættes.» <https://www.ibsen.uio.no/BREV_1871-1879htlB18720321FG.xhtml?soketreff=Ja\&search String $=$ Gjertsen $\&$ fileName $=$ B1871-1879ht.xml\&brevID $=$ B18720321FG $>$ 
diversos àmbits que els ajudaven a resoldre dubtes, com a part fonamental de tot el projecte, una part nosaltres hauríem de suplir, però com?

No respondrem pas a aquestes qüestions en aquest article sobre la retraducció, però sí que aprofundirem en un dels dubtes que van sorgir de refilada, però que considero rellevant per a les reflexions plantejades aquí. La iniciativa partia de la premissa que les traduccions s'editarien en paper, en format llibre, i que la ILC s'encarregaria de buscar editor. Es va suggerir la possibilitat de convidar els teatres a participar en el projecte animant-los a incloure alguna de les obres traduïdes en la seva programació, però tot d'una es va plantejar si la publicació en paper calia perquè, al cap i a la fi, avui dia les obres de teatre es conceben per representar-les i no pas per llegir-les a la butaca de casa, i fins i tot podia resultar anacrònic publicar-ho en format llibre i que caigués en l'oblit en la prestatgeria de clàssics universals. Si fos així, hauríem retraduït Ibsen només perquè forma part del cànon occidental i contribuiríem així a consolidar la noció clàssica de cànon.

Des dels debats contemporanis en el camp de la literatura comparada, els conceptes de literatura universal $i$ de cànon han estat qüestionats d'ençà que els estudis culturals i la literatura postcolonial hi van ocupar un lloc central i els van desbordar. Assumim, doncs, i sense entrar a revisar tot el debat, que la idea d'un únic cànon universal ha quedat desfasada i que la categoria de literatura nacional com a entitat o subjecte literari en la xarxa de relacions entre literatures o sistemes literaris també ha estat superat. Des d'aquesta assumpció, encara tenia menys sentit insistir a retraduir Ibsen únicament per la seva posició en $e l$ cànon universal pensant-nos que dormint el son dels justos podia jugar el paper actiu que té tota literatura traduïda en un sistema literari (tal com l'entén Itamar Even-Zohar). ${ }^{3}$ I aquí tornem a la pregunta inicial, per a qui retraduïm Ibsen avui? L'objectiu del projecte Ibsen in Translation, segons Kolstad, era «to produce versions of Ibsen's texts for the stage, new material for directors willing to stage new translations of Ibsen's work» (Kolstad 2016), proporcionar als directors teatrals versions de les obres d'Ibsen per a l'escenari, un nou material per a directors que vulguin dur a escena els seus drames i transmetre a l'espectador el que li vulguin transmetre i desencadenar emocions íntimes i imprevisibles, no només per al director, sinó també i, sobretot, per a l'espectador.

Així, abans d'emprendre una retraducció de les obres d'Ibsen, calia que ens responguéssim a aquesta pregunta. Al meu entendre l'objectiu de retraduir Ibsen avui coincideix amb el de Kolstad i el projecte d'Ibsen in Translation: tornar a donar la veu a l'Ibsen que avui encara ens commou (aquí rau la seva universalitat), però no des de la lectura que se n'ha fet les darreres dècades (influïda per la crítica esbiaixada dels estudis culturals), massa focalitzada en el tema i com a canalització de causes polítiques i ideològiques (la feminista amb Casa de nines, per exemple), sinó des del vessant literari, artístic.

Per fer-ho, penso que s'hauria d'aprofitar que tenim una bona tradició de traduccions força modernes d'Ibsen (comparat amb el castellà, per exemple, més

3. Vegeu Even-Zohar (2000). 
reticent a introduir un registre més col-loquial) i que som una llengua literària petita més permeable gràcies a la necessitat de nodrir-se d'escrits en altres llengües, i fer que ens parli de nou des de l'escenari, donar-li vida i que cada espectador en tregui aquella veritat que desperta en nosaltres la raó de ser que té tota obra literària i que ens era invisible, que no sabíem que teníem, com deia Goethe, però també que sigui font d'inspiració per a d'altres escriptors, com ho van ser els millors poetes perses per al seu Divan Oriental-Occidental, per exemple.

Per aconseguir-ho, cal aprofundir bé en les particularitats del seu llenguatge, conèixer a fons el que esmentàvem més amunt, els girs, els registres, els jocs lingüístics, el que dona singularitat a la seva veu literària, que poua en el noruec més arrelat. Ja ho assenyalava el crític danès Georg Brandes el 1899, en un article sobre els perills de la literatura universal:

La literatura universal del futur serà més captivadora com més forta sigui l'empremta nacional que se'n desprèn, i com més diversa sigui, ja que només com a obra d'art i com a font de coneixement assoleix la universalitat. (Brandes 1899)

Entenent que és des de la genuïnitat que arriba a la universalitat, fora bo reproduir en català la seva originalitat en el sentit més extens perquè Ibsen torni als escenaris de la mà d'aquell director que se senti mogut a endinsar-s'hi de nou, a qui hagi revelat una veritat íntima i la vulgui compartir amb els espectadors perquè a ells, també i al seu torn, els reveli les seves veritats íntimes.

Vist així, la traducció hauria de ser un espai de trobada, tal com diu Lawrence Venuti:

To translate is to invent for the foreign text new readerships who are aware that their interest in the translation is shared by other readers, foreign and domestic, even when those interests are incommensurable. (Venuti 2000)

És una comunitat imaginada, en termes de Benedict Anderson, en què utòpicament coincidiran els lectors d'allò més diversos, però amb un interès comú per l'obra traduïda. És una projecció de futur, com la de Goethe i la Weltliteratur, empesa per l'aspiració a apropar cosmovisions, a acostar-te a l'altre per acostar-te a tu mateix.

És així que podrem conferir a l'obra dramàtica de Henrik Ibsen, retraduint-la, una universalitat renovada i, a la vegada, defugir les diatribes sobre les definicions de cànon o de literatura universal.

\section{Referències bibliogràfiques}

Brandes, G. (1902). «Weltlitteratur». A: Das litterarische Echo, núm. 1 del segon any, Deutsch-Oesterreichischen Litteratur-Gesellschaft, F. Fontane Verlag. L'article es publicar per primera vegada l'any 1899 en alemany i posteriorment va ser traduit al danès amb el títol «Verdensliteratur» per incloure'l a l'obra completa de BRANDES, G.: Samlede Skrifter (1899-1910), volum XII (1902), p. 23-28 (en aquest article en citem l'edició danesa). 
Casanova, Pascale (2002). «Consécration et accumulation de capital littéraire». Actes de la recherche en sciences sociales, 144 (1), p. 7-20.

Even-Zohar, Itamar (2000). «The Position of Translated Literature within the Literary Polysystem». Poetics Today, 11 (1), p. 45-51.

Gómez-Baggethun, Cristina (2016). «The Experience of Translating Ibsen's Plays into Spanish». Palimpsestes, 29.

<https://doi.org/10.4000/palimpsestes.2345>

Kolstad, Ellinor (2016). «Ibsen—not Lost in Translation». Palimpsestes, 29.

$<$ https://doi.org/10.4000/palimpsestes.2343>

Venuti, Lawrence (2000). «Translation, community, utopia». A: Venuti, Lawrence (ed.). The Translation Studies Reader. Nova York: Londres: Routledge, p. 495. 